\title{
New discoveries in the frog Latonia seyfriedi (Anura: Alytidae) and their impact on taxonomy of the genus Latonia
}

\author{
Elena Syromyatnikova ${ }^{1,2}\left(\right.$ Zbyněk Roček $^{3}$ (D) Sabrina van de Velde ${ }^{4}(\mathbb{D}$
}

Received: 19 October 2018 / Accepted: 23 May 2019

(c) Paläontologische Gesellschaft 2019

\begin{abstract}
Latonia seyfriedi, the type species of the genus Latonia, was described by von Meyer (1843) based on an articulated skeleton from the middle Miocene (Serravallian) of Öhningen, Germany. Besides the holotype, four additional articulated skeletons are known from the type locality; all display only the ventral aspect. A similar frog reported by Lartet (1851) from the middle Miocene of Sansan, France was later assigned to the genus Latonia as L. gigantea based on disarticulated skull roof bones covered with sculpture. In the course of time, similar bones were recovered from numerous localities, but, because the dorsal surface of the cranial roof was not known for $L$. seyfriedi, they were mostly identified as $L$. gigantea. The crucial question of whether the skull roof bones of L. seyfriedi, especially the frontoparietal and maxilla, bear sculpture or not remained unresolved until recently, when specimen TMH 8438 from Öhningen was made available for micro-computed tomography (CT) investigations. The present study reveals that the frontoparietal is covered by pustular sculpture as in the L. gigantea neotype, and that the sculpture on the maxillae is similar in both taxa. Since other bones are also similar, we suggest that $L$. gigantea is a junior synonym of $L$. seyfriedi. Micro-CT scanning of TMH 8438 made it possible to reconstruct the original positions of the bones. It turned out that the nasals are sculptured and overlapped with the frontal processes of the maxillae as well as with the anterior end of the frontoparietal. This allowed us to reconstruct the shape and proportions of the skull.
\end{abstract}

Keywords Latonia seyfriedi $\cdot$ Latonia gigantea $\cdot$ Anura $\cdot$ Miocene $\cdot$ Öhningen

\section{Introduction}

Handling Editor: Nadia Fröbisch.

Elena Syromyatnikova

esyromyatnikova@gmail.com; sev@paleo.ru

Zbyněk Roček

Rocek@gli.cas.cz

Sabrina van de Velde

sabrina.vandevelde@naturalis.nl

1 Borissiak Paleontological Institute of the Russian Academy of Sciences, Profsoyuznaya 123, Moscow 117647, Russia

2 Zoological Institute of the Russian Academy of Sciences, Universitetskaya emb. 1, St. Petersburg 199034, Russia

3 Laboratory of Palaeobiology, Institute of Geology, Czech Academy of Sciences, Rozvojová 135, 16500 Prague, Czech Republic

4 Naturalis Biodiversity Center, Vondellaan 55, 2332 AA Leiden, The Netherlands
Frogs of the genus Latonia are among the most common fossil anurans in Europe (Roček 2013). Their earliest known records are from the late Oligocene, and one species still survives today in the eastern Mediterranean (Biton et al. 2013). Six species are currently recognized: $L$. seyfriedi von Meyer, 1843 , for which the type species was recovered from the middle Miocene of Öhningen, Germany; L. gigantea (Lartet, 1851) from the middle Miocene of Sansan, France; L. vertaizoni (Friant, 1944) from the late Oligocene of Vertaizon, France; L. ragei Hossini, 1993 from the early Miocene of Laugnac, France; L. nigriventer (Mendelssohn and Steinitz, 1943) from the Pleistocene and Recent of Israel (Biton et al. 2013, 2016); and L. caucasica Syromyatnikova and Rocek (2018) from the late Miocene of Volchaya Balka, Russia (Syromyatnikova and Roček 2018).

Latonia seyfriedi was described based on an articulated, three-dimensionally (3D)-preserved skeleton, deposited in the Staatliches Museum für Naturkunde Karlsruhe (SMNK, uncatalogued) embedded in matrix by its dorsal side, thus 
exposed only by its ventral aspect (von Meyer 1845: pl. 4; see also Roček 1994: fig. 1). Roček (1994) revised the holotype and two additional specimens stored in the Paläontologisches Institut und Museum of the University in Zurich (PIMUZ A/II 28 and A/II 27; see Roček 1994: figs. 3, 4; von Meyer 1845: pl. 6, fig. 1) that were also from the type locality. As is the case with the holotype, PIMUZ A/II 28 and PIMUZ A/II 27 are also exposed by their ventral side, but only the posterior part of the vertebral column is preserved in PIMUZ A/II 27 (apart from a few scattered bones in its vicinity) and its vertebrae are slightly displaced (von Meyer 1845: pl. 6, fig. 1; Roček 1994: fig. 4). Note, however, that some bones were lost in the course of time. Another, unpublished specimen from Öhningen is deposited in the Natural History Museum in London under catalogue no. 42739 (Fig. 1), and a nearly complete, articulated skeleton from the same locality is deposited in Teylers Museum, Haarlem as TMH 8438. Thus, all specimens from the type locality are exposed exclusively in their ventral aspect, which prevents

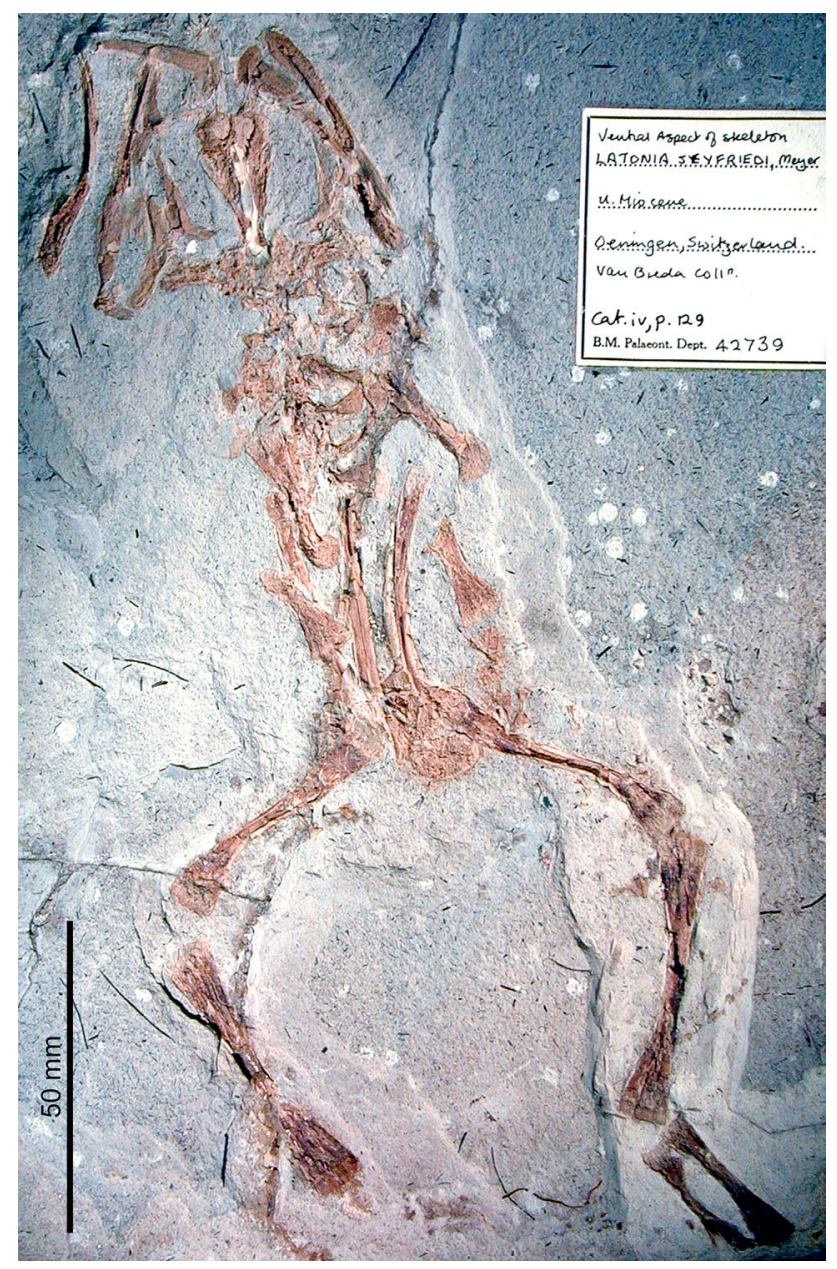

Fig. 1 Latonia seyfriedi von Meyer, 1843 (specimen NHMUK 42739). Image by permission of the Natural History Museum in London observation of the dermal bones of the dorsal side of the skull.

Shortly after von Meyer's publications of this giant fossil frog (Latonia may reach an estimated snout-vent length of $20 \mathrm{~cm}$, measured from the symphysis of the premaxillae to the tip of the urostyle), Lartet (1851: 41) published a note on a large anuran with a sculptured outer surface of maxillae from the Sansan locality in France, which he assigned to Rana. Lydekker (1890) reassigned it to Latonia, as L. gigantea. Roček (1994) and Rage and Hossini (2000) at about the same time tried to describe diagnostic characters that would distinguish $L$. seyfriedi and $L$. gigantea (both manuscripts were prepared simultaneously and in mutual cooperation, but the date of publication of the latter was much delayed). However, their effort suffered from the fact that the L. gigantea description was based on isolated dermal bones, especially frontoparietals and maxillae whose surfaces were covered with sculpture, whereas these features could not be verified for $L$. seyfriedi, because the dorsal surface of the bones of the skull roof were buried in sediment. Rage and Hossini (2000) then designated a neotype for L. gigantea (MNHN Sa 23448; Fig. 2; see also Rage and Hossini 2000: fig. 8d, v) because Lartet did not designate any particular specimen as a type. This inconvenient situation lasted while numerous Latonia finds from many localities in Europe (e.g., Götzendorf, Przeworno, etc.) were assigned either to L. seyfriedi or to L. gigantea, disregarding the main diagnostic feature for distinguishing both species: the presence or absence of sculpture on dermal cranial bones. Because most Latonia remains recovered from numerous Neogene localities are represented by disarticulated bones,
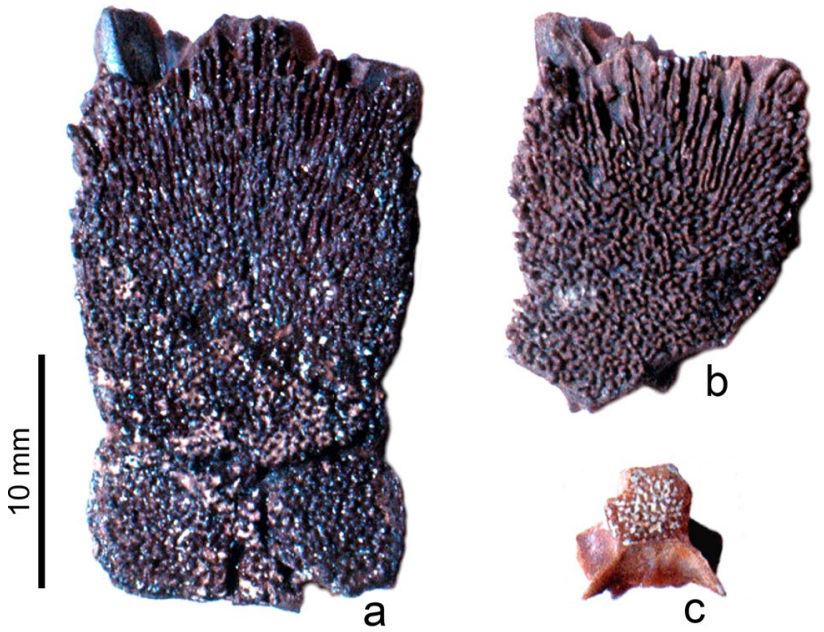

Fig. 2 Latonia gigantea (Lartet, 1851). a Frontoparietal in dorsal aspect (neotype MNHN Sa 13448); b anterior part of frontoparietal of slightly younger individual in dorsal aspect (MNHN Sa 13489); c posterior part of frontoparietal in young individual (MNHN Sa 13453). All from the Sansan locality. See also Roček (1994: fig. 7a, e, f) and Rage and Hossini (2000: figs. 8, 11) 
usually they were automatically assigned to L. gigantea . It was clear that, if it could be proven that frontoparietals and maxillae are sculptured in $L$. seyfriedi, then L. gigantea should become a junior synonym of $L$. seyfriedi.

A possibility to solve this problem appeared with the introduction of nondestructive micro-CT scanning, and a nearly complete articulated skeleton of Latonia (TMH 8438; Fig. 3) from the type locality was made available by the Teylers Museum, Haarlem. We assume that all five known topotypic specimens from Öhningen belong to a single species, L. seyfriedi. Besides the holotype specimen, which was found in the bottom layers ("Kesselstein") of the lower quarry (Ziegelhof) north of Wangen in 1840 (sites that do not exist today were collectively termed "Öhninger Fundstätten"), there was a specimen recovered in 1837 , consisting of isolated hindlimbs (von Meyer 1845: pl. 5, fig. 1), the above-mentioned PIMUZ A/II 27, and PIMUZ A/II 28. The three specimens mentioned last are deposited in the Paläontologisches Institut und Museum of the University in Zurich. A counterpart of PIMUZ A/II 28 (Roček 1994: fig. 3) is NHMUK 42739 (Fig. 1), which is deposited in the Natural History Museum in London. The fifth specimen is TMH 8438 deposited in Teylers Museum, Haarlem (Fig. 3). All these specimens were collected in the first half of the 19th century, and they were originally deposited in various collections (Lavater, Schuthess) in Zurich, from which some were sold to the collection (Van Breda) in Haarlem, and the counterpart of PIMUZ A/II 28 was sold to London in 1871. This history, together with the morphological properties of the sediment, suggests that all these specimens came from the lower Öhningen quarry, Ziegelhof. In addition, the holotype specimen, PIMUZ A/II 28 + NHMUK 42739, and TMH 8438 are preserved in the same position, which makes it possible to compare many of their skeletal (especially, cranial) elements in situ. These comparisons revealed that no differences could be found, which would suggest the possibility that any of these three, or even the remaining two specimens that are incompletely preserved, belong to different species. Thus, it is possible to consider them the type series, according to Art. 72.1.1 and Art. 72.4.1 of ICZN (International Commission of Zoological Nomenclature 1999). We restricted our investigations to cranial characters, because the crucial distinguishing features between $L$. seyfried $i$ and L. gigantea are on the skull.

\section{Methods}

The specimen of $L$. seyfriedi described herein originated from the middle Miocene (MN 6-7; Selmeier 1990) of Öhningen (type locality), Germany. It was examined by micro-computed tomography (micro-CT) using the facilities available at the Naturalis Biodiversity Center (Leiden, The Netherlands). The

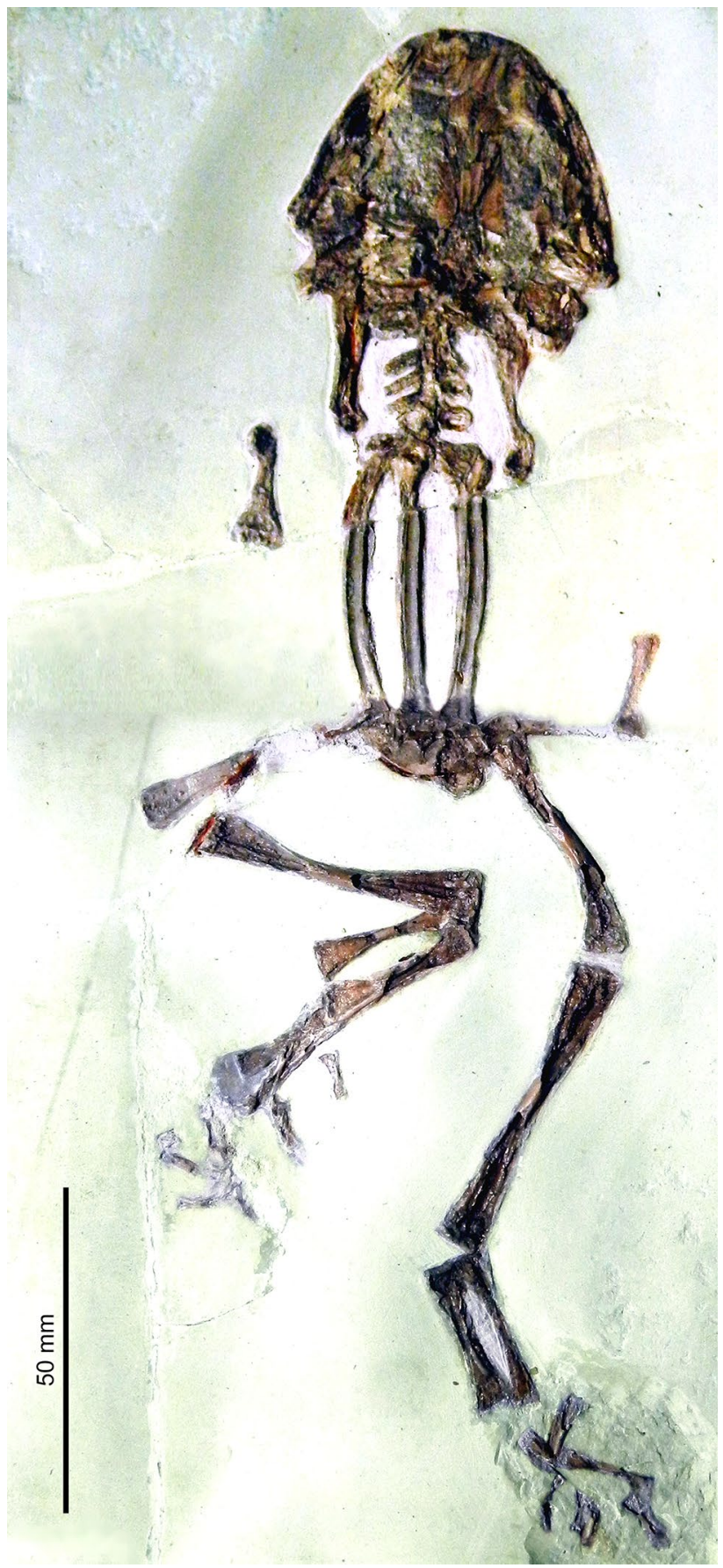

Fig. 3 Latonia seyfriedi von Meyer, 1843 (specimen TMH 8438)

specimen was scanned with the assistance of Rob Langelaan (research analyst at Naturalis Biodiversity Center), with a Zeiss Xradia Versa 520, which uses a tungsten source $(160 \mathrm{kV}$, $10 \mathrm{~W}$, and $63 \mathrm{~mA}$ ). A total of four scans were made, each consisting of 1600 images, by scanning four times a " $180+$ fan" scan that started at $-93^{\circ}$ and finished at $93^{\circ}$. The images were collected with a $0.4 \times$ optical magnification detector (Andor, iKon-L), and an exposure time of $10 \mathrm{~s}$. The four scans where 
then placed on and next to each other, resulting in an image with dimensions of $1524 \times 1900$ pixels. The wide scan reconstructions were carried out using the Reconstructor Scout-andScan program, and stitched together using the Manual Stitcher Scout-and-Scan program. The total reconstruction consisted of 1524 8-bit tiff files, each with dimensions of $1884 \times 1900$ pixels. No downsampling was applied while making the reconstructions. The final reconstruction had a pixel size of $34.3471 \mu \mathrm{m}$. Isosurfaces were prepared with Avizo 8 (FEI Visualization Sciences Group). Comparisons were made with the following Latonia specimens (based on literature data and own observations): holotype of $L$. seyfriedi (SMNK uncatalogued; von Meyer 1845: table 4; Roček 1994: figs. 1, 2) and additional specimens of $L$. seyfriedi (PIMUZ A/II 28 and A/II 27; Roček 1994: figs. 3, 4) from the middle Miocene of the type locality Öhningen, Germany; holotype of L. vertaizoni (FSL 150.900) from the upper Oligocene of the type locality Coderet, France (Roček 1994); neotype of L. gigantea (frontoparietal, MNHN Sa 13489; Roček 1994: fig. 7f) from the middle Miocene of the type locality Sansan, France, as well as other numerous isolated bones assigned to L. gigantea from different localities (Gervais 1859; Bolkay 1913; Wettstein-Westersheimb 1955; Špinar 1975, 1978; Młynarski 1976; Roček 1994, 2005, 2013; Sanchiz 1998a; Rage and Hossini 2000; Hír et al. 2001; Venczel 2001, 2004; Miklas 2002; Venczel and Ştiucă 2008; Prieto et al. 2009; Böhme 2010; Venczel and Hír 2013, 2015 Villa et al. 2017); holotype of $L$. ragei (maxilla, FSL 150.800) from the lower Miocene (Agenian) of the type locality Laugnac, France, and other isolated bones assigned to L. ragei (Hossini 1993; Roček 1994, 2013; Sanchiz 1998b), Latonia cf. ragei (Sanchiz 1998a), and Latonia aff. ragei (Rage and Bailon 2005) from different localities; L. nigriventer (Biton et al. 2013, 2016); X-ray microtomography scans of extant specimens and isolated Pleistocene bones of $L$. nigriventer (Biton et al. 2013, 2016); as well as isolated material of Latonia sp. (Delfino 2002; Villa et al. 2017). The osteological terminology of Latonia follows that of Roček (1994) and Špinar (1978).

Institutional abbreviations. FSL-Centre des Sciences de la Terre, Université Claude-Bernard, Villeurbanne, France; MNHN-Muséum National d'Histoire Naturelle, Paris, France; NHMUK - Natural History Museum, London, UK; PIMUZ_Paläontologisches Institut und Museum, Universität Zürich, Switzerland; SMNK — Staatliches Museum für Naturkunde, Karlsruhe, Germany; TMH-Teylers Museum, Haarlem, The Netherlands.

\section{Results}

As is the case with all known individuals of Latonia from Öhningen, the TMH 8438 skeleton is not only exposed in ventral aspect, but it is also strongly dorsoventrally compressed. Moreover, in TMH 8438, the braincase (including the sphenethmoid and both otic capsules), palatal portion of the skull (vomers, parasphenoid, pterygoids), and lower jaw were split away, so only bones of the skull roof were preserved. This is why the ventral surface of the frontoparietal is exposed in the original specimen (Fig. 4), with the extensive, smooth surface of the tectum supraorbitale protruding on both sides into the orbits. A similar situation occurred with large nasals, whose ventral surfaces display extensive facets for the contact with the sphenethmoid. Besides that, the complete, articulated left squamosal is preserved on the right side, as well as marginal, tooth-bearing portions of both maxillae and premaxillae, although they are considerably crushed. The quadratojugals are preserved on both sides, but disarticulated and slightly displaced. The vertebral column seems to be slightly pushed against the posterior part of the skull, and the vertebrae are also crushed.

Although the snout-vent length (SVL) of TMH 8438 is difficult to estimate (especially because of partly obscured anterior section of the vertebral column), it may be about $120 \mathrm{~mm}$, which corresponds to an adult, but not fully grown individual (SVL in the holotype of $L$. seyfriedi is estimated to be $162 \mathrm{~mm}$ ). The anteroposterior diameter of the preserved portion of the frontoparietal is about $16 \mathrm{~mm}$, which is less than that in the neotype of L. gigantea (at least $24 \mathrm{~mm}$; Rage and Hossini 2000). These differences in size and also the fact that in TMH 8438 the pineal foramen is still discernible, whereas in the neotype of L. gigantea it is fully obliterated except for a depression in the tubercular sculpture, suggest a probable earlier stage of postmetamorphic development.

In spite of the younger stage of ontogenetic development for TMH 8438 than that of the holotype, which was a fully

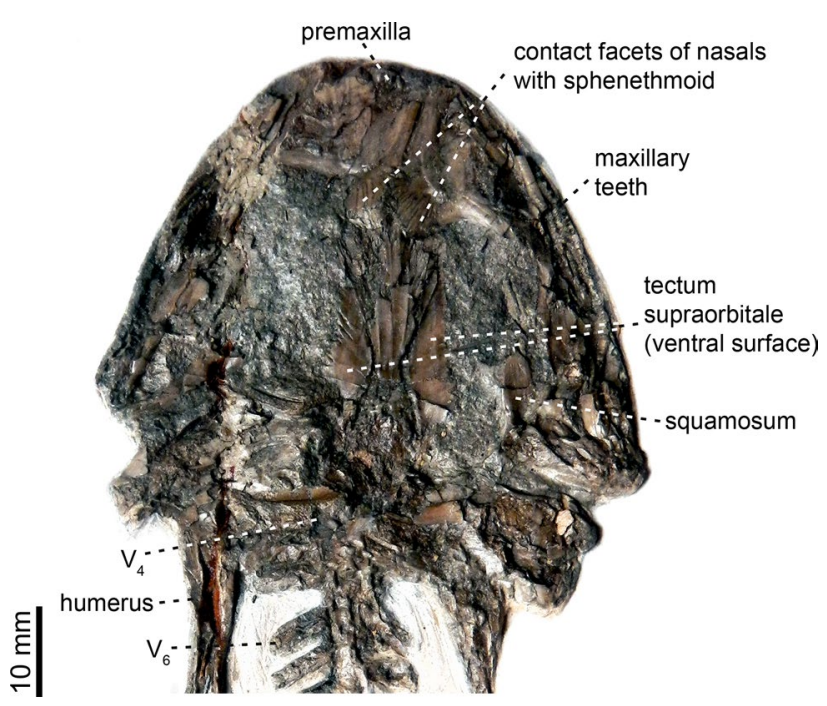

Fig. 4 Latonia seyfriedi von Meyer, 1843 (TMH 8438): exposed ventral surface of the skull roof. The braincase and palatal portion of skull are broken away 
grown adult, the dermal bones of the skull roof bear a welldeveloped sculpture. This is the most important discovery revealed by CT scan of this specimen. The frontoparietal, nasals, maxillae, squamosals, and probably also quadratojugals are covered with tubercular or ridge-like sculpturing, similar to that of $L$. gigantea. It consists of radially oriented ridges manifested by their tubercle-like ends on the posterior two-thirds of its dorsal surface, and fan-like oriented ridges in the anterior third. The tectum supraorbitale in TMH 8438 consists of fused, horizontal ridges (observable in Fig. 5 due to lower resolution), interconnected, and covered ventrally by only a thin horizontal layer (Fig. 4). In contrast, the middle portion of the bone which covers the frontoparietal fenestra of the braincase dorsally, and which is pierced by the pineal foramen (incorrectly called the parietal foramen by Roček 1994: fig. 7e), is thick. Thus, the sculpture of the frontoparietals in L. seyfriedi and L. gigantea does not display any significant difference.
In both maxillae, an easily discernible patch of tubercular sculpture occurs below the zygomaticomaxillar process (Fig. 5e-g), with signs that the tubercles or short ridges are secondary condensations on the surface of the bone. Closer examination of the material from Sansan in 1992 by one of us (Roček 1994: figs. 10, 11) revealed that, in large individuals, the tubercular sculpture of maxillae is attached to the smooth external surface of the bone by a layer of bony trabeculae that are rather fragile and may be crushed in fossil bones. This may cause artificial losses of sculpture. This suggests that the sculpture in Latonia is a secondary deposition that only later fused to the underlying bone. A similar situation may occur with sculpture on the nasals, in which the paraorbital and anterior processes remain unsculptured, due to their overlap with the frontal process of the maxilla and facial part of the premaxilla, respectively.

The micro-CT scan not only revealed presence of sculpture on dermal bones in TMH 8438 (thus, in L. seyfriedi), but

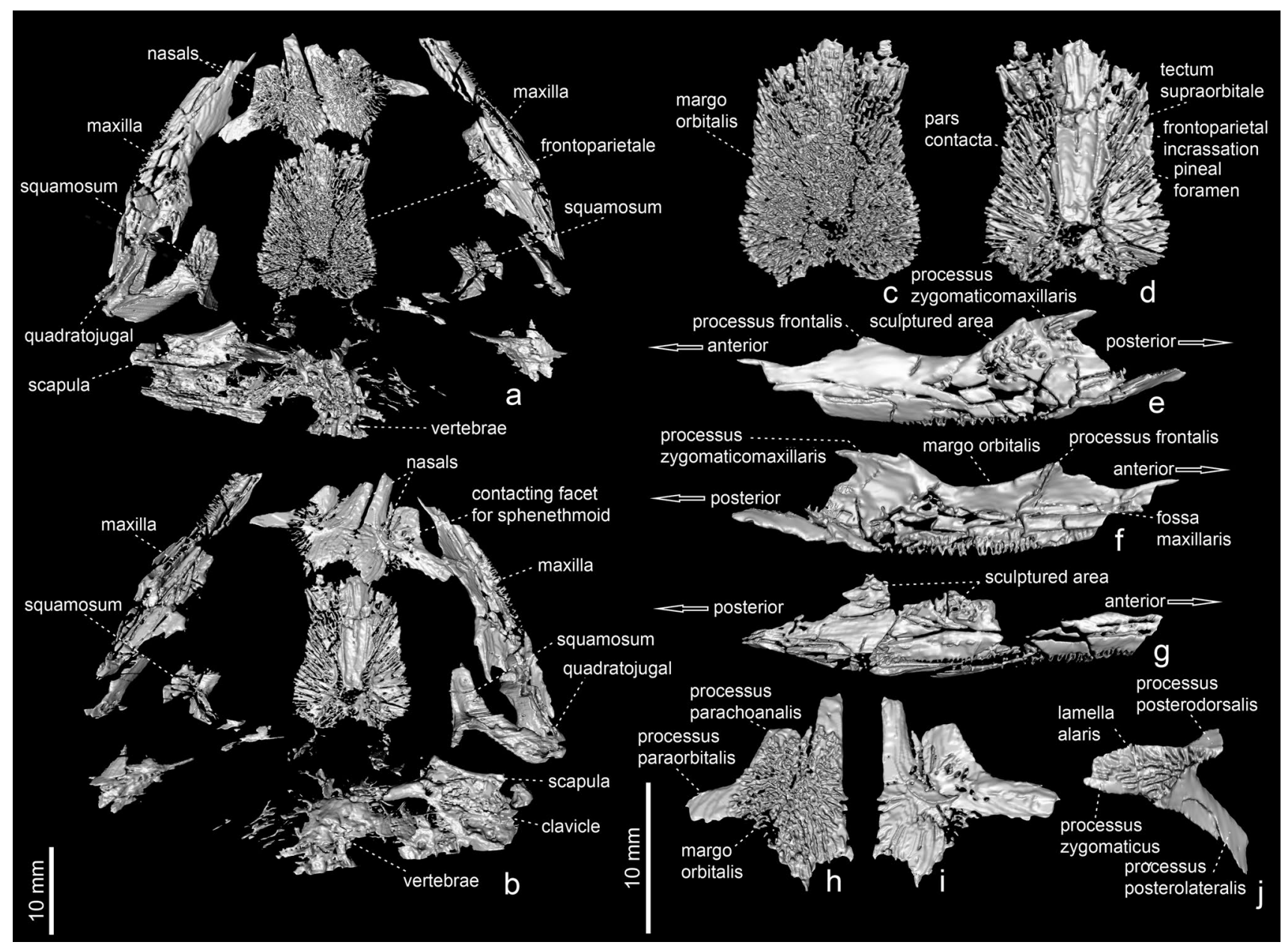

Fig. 5 Latonia seyfriedi von Meyer, 1843 (TMH 8438). a, b CT scans of skull roof in dorsal (a) and ventral (b) aspects; c, d frontoparietal in dorsal (c) and ventral (d) aspects (see Roček 1994: fig. 7f); e, f left maxilla in lateral (e) and medial (f) views (see Roček 1994: figs. 9-11); $\mathbf{g}$ right maxilla in lateral view; $\mathbf{h}$, $\mathbf{i}$ left nasal in dorsal (h) and ventral (i) views; j left squamosal in lateral view (see Roček 1994: pl. 1, fig. 1) 
also, because the dermal bones in this particular specimen were only slightly displaced, we could restore their original position in the skull in both dorsal and ventral views (Fig. 6). It is obvious that the maxillary arch was complete, including the quadratojugals (previously known only from PIMUZ A/ II 28). Furthermore, the paraorbital process of nasals was extensively overlapped by the frontal process of the maxillae, and the articular facet for the sphenethmoid on the ventral surface of the nasals was delimited by a low, archlike ridge that continued posterolaterally onto the ventral surface of the frontoparietal, where it is manifested as the prominent, thin wall termed the pars contacta (Roček 1994: fig. 7f). In addition, the lamella alaris squamosi (namely its processus zygomaticus) was inserted into a broad concavity in the dorsal margin of the zygomaticomaxillar process of the maxilla (compare Fig. 6b with Fig. 5e, f).

\section{Discussion}

The confusing situation that stems from taxonomic incertitude concerning two closely related species of giant Miocene frog Latonia was exacerbated by their different ways

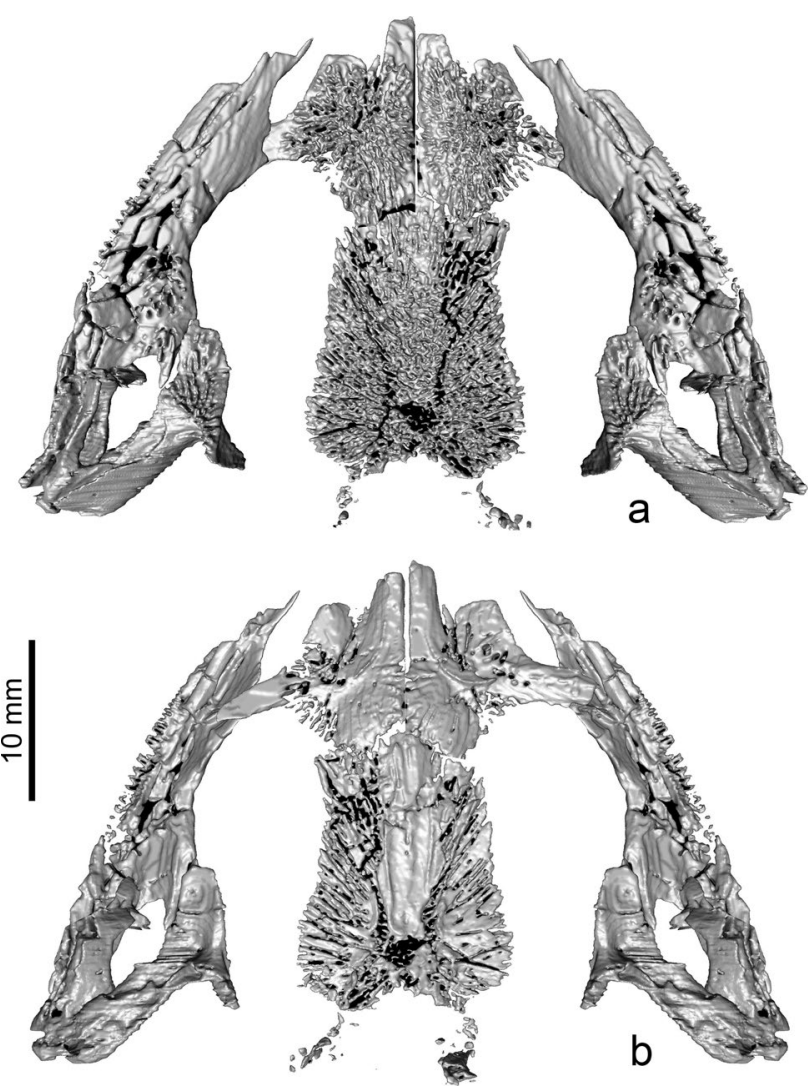

Fig. 6 Reconstruction of the skull roof in Latonia seyfriedi von Meyer, 1843 in dorsal (a) and ventral (b) views. Based on TMH 8438 (reconstruction courtesy of Paula Muzzopappa) of fossilization. Whereas Latonia seyfriedi von Meyer, 1843 was primarily preserved as articulated skeletons from a currently nonexistent locality Öhningen (Ziegelhof), and no further specimens were found after its closure in the middle of the 19th century, L. gigantea (Lartet, 1851) was based on disarticulated bones. This no doubt influenced determination of further findings-because no articulated skeletons were found and all findings were represented by disarticulated bones, specimens were in their vast majority assigned to L. gigantea. Consequently, it could be inferred from numerous faunal lists that the dominant Miocene Latonia species was $L$. gigantea, while $L$. seyfriedi was restricted to only Öhningen.

However, the situation was not as simple as it would seem, and determination was not based only on the fact that a fossil was preserved as articulated skeleton or as disarticulated bones. Because all articulated skeletons were exposed by their ventral side, and their dorsal side was embedded in matrix, it was not possible to detect whether the dermal roofing bones of $L$. seyfriedi were covered by sculpture, as is the case with L. gigantea. The neotype of L. gigantea is the large, densely sculptured frontoparietal (Fig. 2a; Roček 1994: fig. 7f; Rage and Hossini 2000: fig. 8) obviously belonging to a fully grown adult, which could be reasonably compared with the holotype of $L$. seyfriedi, also undoubtedly an adult. Frontoparietals of $L$. gigantea from Sansan are preserved in various developmental stages, from which it was apparent that their sculpture developed and changed with age (Roček 1994: fig. 7a-f). Similar juvenile frontoparietals were found, e.g., in Gritsev (Roček, pers. obs.). Moreover, the frontoparietals of L. gigantea from Sansan were associated with maxillae, which were also sculptured, but only in a restricted field on the basis of the processus zygomaticomaxillaris. This field on the maxillae of adults varies both in type of sculpture and extent (Roček 1994: fig. 10e, f; Rage and Hossini 2000: fig. 10), and this variation is not associated with individual age. It therefore turned out to be crucial to know whether $L$. seyfriedi was sculptured at least on the frontoparietal and maxillae, because then those two bones could be compared with L gigantea. It could theoretically be possible that these two bones were without any sculpture, as suggested by the completely smooth maxillae of $L$. ragei (Hossini 1993) from the lower Miocene of Laugnac, in which, however, frontoparietals are not known.

Therefore, it would be logical to try to prepare the holotype specimen of $L$. seyfriedi in a way that would allow observation of at least part of the dorsal frontoparietal surface. Given that the specimen suffered serious damage during a bombing raid at the end of WWII (it was broken into two halves and had to be glued together again), these considerations were not reasonable. A new possibility appeared when micro-CT scanning started to be used for noninvasive investigation of fossils. This, however, was 
for various reasons also impossible in the case of the holotype specimen. Such a possibility only appeared with the specimen TMH 8438, which originally came, together with other specimens of Latonia now deposited in Zurich, from Lavater's collection, from where it was forwarded to the Dutch biologist and geologist Jacob Van Breda, who was the head of palaeontological cabinet in Haarlem. Thus, it was possible to trace the origin of this specimen, similar to other mentioned Zurich specimens, back to the lower Öhningen quarry, Ziegelhof (the upper quarry called Salenhof yielded mainly plant fossils). It should be emphasized that there were several quarries in the Öhningen vicinity where fossils were collected since the beginning of $1700 \mathrm{~s}$ (Stauber 1939), but only these two seem to have survived until the middle of the 19th century (the holotype specimen was found as the last of its series in 1840; von Meyer 1845). A similar situation exists with Chelotriton, which is also represented in Öhningen by several individuals deposited in various collections in Europe, but without precise collecting data (Westphal 1978).

We were able to investigate and document all five individuals from Öhningen, compare them with each other, and also compare them with large series of L. gigantea from Sansan, and with $L$. ragei from Laugnac, although the disadvantage is that the frontoparietal of the latter species remained unknown; results of these comparisons are partly summarized in Roček (1994). Thus, the main focus of this paper is on the presence or absence of sculpture on those bones of $L$. seyfriedi that could allow comparisons with $L$. gigantea.

Because it is now clear that both $L$. seyfriedi and L. gigantea bear sculpture on their cranial dermal bones, their frontoparietals are the same in shape, and their maxillae are sculptured in the area covering the basis of the zygomaticomaxillar process, a revision of all other available features, including those on the postcranial skeleton, should be made. This is necessary, because if any taxonomically important differences were to be found, they could support the separated status of both species. Although our investigations brought new, hitherto unknown results (shape of nasals and their articulations with the maxillae and frontoparietal, shape of the squamosals and their positions in situ, quadratojugals, and even shape of the dorsal part of the braincase reflected on the inner surface of the frontoparietal and nasals), they are very difficult to compare with selectively preserved, disarticulated bones of L. gigantea. In addition, comparisons should be done only with material from Sansan, the type locality of L. gigantea, which is available in large amounts, but it is not known whether differences within this material are due to individual variation or if they reflect taxonomic differences (e.g., variation of angulars; Roček 1994: fig. 12g-i). Large individual variation probably exists in shape of the urostyles, as evidenced by L. ragei from the lower Miocene of Laugnac (Roček 1994: fig. 15a, d).
While taking into account the possible individual variation of fully grown adults, it is possible to restrict the comparisons to those characters that are considered diagnostic for the species, not for the genus. Moreover, it should be taken into account that the postcranial skeleton in the anurans is more uniform than the skull, and that some bones (e.g., humerus) may reflect sexual dimorphism. Rage and Hossini (2000) thus came to the conclusion that Latonia from Sansan and Öhningen may differ only in the morphology of their coracoids. At the same time, however, they noted that two specimens described and illustrated by von Meyer (1845: pl. 4 and pl. 6, fig. 1) display coracoids that seem to be identical to those from Sansan (Rage and Hossini 2000: fig. 15). In regards to the shape of the sacral wings, it would seem that their anterior margin is more perpendicular to the main body axis in L. seyfriedi than in L. gigantea (compare Roček 1994: figs. 2, 3, 4 and Rage and Hossini 2000: fig. 20), but because they are reconstructed from fragments of bones combined with imprints in the matrix, this conclusion could be due to preservational artifact. It is therefore impossible to find some reliable distinguishing characters between $L$. seyfriedi and $L$. gigantea.

Compared with other Latonia spp., L. seyfriedi clearly differs from the early Miocene species (L. ragei and $L$. vertaizoni) by having sculptured maxilla. Among the recently described species, $L$. seyfriedi differs from $L$. nigriventer by having clearly sculptured frontoparietal, maxilla, nasal, and squamosal and from L. caucasica by sculptured maxilla and squamosal.

New recent discoveries, of which the most important is the discovery of extant $L$. nigriventer (Biton et al. 2013, 2016), will hopefully be an impetus for another comparative analysis among currently recognized species of Latonia and their revision, which is a necessary prerequisite for reconstruction of the evolutionary history of this genus.

\section{Conclusions}

New observations gained from micro-CT reconstruction of the skull roof and associated bones made it possible to add further characters to the diagnosis of Latonia seyfriedi. This especially concerned sculpture on the dermal bones of the skull roof, which is basically the same as in L. gigantea. Because the presence or absence of sculpture was the most important character for distinguishing these two species, it may be concluded that its presence in $L$. seyfriedi von Meyer, 1843 results in considering L. gigantea (Lartet 1851) a junior synonym of the former.

The emended diagnosis of $L$. seyfriedi should then be as follows: frontoparietal, maxilla (ventral portion of its zygomaticomaxillar process), nasal, and squamosal (its lamella alaris) are covered with pustular or ridge-like sculpture; 
frontoparietal has both its orbital margins slightly converging towards the anterior.

Acknowledgements We thank Alexey Tesakov (Geological Institute, Russian Academy of Sciences, Moscow, Russia), who greatly assisted in organization of CT scanning, and Paula Muzzopappa (CONICET, Fundación Azara, Caba, Argentina), who made the reconstruction of the skull roof of Latonia (Fig. 6) during her long-term visit to the Department of Palaeobiology, Geological Institute of the Academy of Sciences, Prague. Sandra Chapman (Natural History Museum, London) provided additional information on the London specimen; Anne S. Schulp, Herman J. Voogd, and Jan Willem Pette (Teylers Museum, Haarlem) provided technical assistance. Dirk van der Marel, Arjen Speksnijder, and Rob Langelaan (Naturalis Biodiversity Center, Leiden) helped with CT scanning. Alexander Averianov (Zoological Institute of the Russian Academy of Sciences) and Dmitry Ponomarenko (Borissiak Paleontological Institute of the Russian Academy of Sciences) helped with data visualizations. We would like to acknowledge also the late Jean-Claude Rage for valuable discussions on relationships between Latonia seyfriedi and $L$. gigantea. We thank Nadia Fröbisch and two anonymous reviewers for their critical comments. E.S. was supported by the government theme AAAA-A17-117030310017-8 (Russia) and the Russian Foundation for Basic Research, Grants № 19-04-00514; Z.R. was supported from the research plan of the Institute of Geology of the Czech Academy of Sciences (RVO67985831).

Author contributions The coauthors of this paper made the following contributions: S.V. scanned the specimen; E.S. worked on CT scan reconstruction and prepared an early version of the manuscript; Z.R. provided the data on L. gigantea and other specimens of $L$. seyfriedi, and prepared the last version of the manuscript; all authors contributed to manuscript preparation and approved the manuscript.

\section{References}

Biton, R., R. Boistel, R. Rabinovich, S. Gafny, V. Brumfeld, and S. Bailon. 2016. Osteological observations on the alytid anura Latonia nigriventer with comments on functional morphology, biogeography, and evolutionary history. Journal of Morphology 277 (9): 1131-1145.

Biton, R., E. Geffen, M. Vences, O. Cohen, S. Bailon, R. Rabinovich, Y. Malka, T. Oron, R. Boistel, V. Brumfel, and S. Gafny. 2013. The rediscovered Hula painted frog is a living fossil. Nature Communications 4: 1959. https://doi.org/10.1038/ncomms2959.

Böhme, M. 2010. Ectothermic vertebrates (Actinopterygii, Allocaudata, Urodela, Anura, Crocodylia, Squamata) from the Miocene of Sandelzhausen (Germany, Bavaria) and their implications for environment reconstruction and palaeoclimate. Paläontologische Zeitschrift 84: 3-41.

Bolkay, S. 1913. Additions to the fossil herpetology of Hungary from the Pannonian and Praeglacial periods. Mittheilungen aus dem Jahrbuch der königlichen Ungarischen geologischen Reichsanstalt 21: 217-230

Delfino, M. 2002. Erpetofaune italiane del Neogene e del Quaternario. Unpublished PhD Thesis, Università degli Studi di Modena e Reggio Emilia, Modena.

Gervais, P. 1859. Zoologie et Paleontologie francaises. Nouvelles recherches sur les animaux vertébrés dont on trouve les ossements enfouis dans le sol de la France et sur leur comparaison avec les espèces propres aux autres régions du globe, 2nd ed. Paris: Arthus Bertand.

Friant, M. 1944. Caracteres anatomiques d'un batracien oligocene de la Limagne, le Prodiscoglossus Vertaizoni nov. gen. nov. spec.
Comptes-Rendus Hebdomadaires des Seances de l'Academie des Sciences 219: 561-562.

Hír, J., J. Kókay, M. Venczel, E. Gál, and E. Kessler. 2001. A preliminary report on the revised investigation of the paleontological locality-complex "Güdör-kert" at Felsôtárkány, Northern Hungary. Folia Historico-Naturalia Musei Matraensis 25: 41-64.

Hossini, S. 1993. A new species of Latonia (Anura, Discoglossidae) from the lower Miocene of France. Amphibia-Reptilia 14: 237-245.

International Commission of Zoological Nomenclature. 1999. International Code of Zoological Nomenclature. $4^{\text {th }} \mathrm{ed}$. http://www.nhm. ac.uk/hosted-sites/iczn/code/. (Accessed 25 Jan 2019).

Lartet, E. 1851. Notice sur la Colline de Sansan, Suivie D'une Récapitulation des Diverses Espèces d'animaux Vertébrés Fossiles, Trouvés soit à Sansan, soit dans D'autres Gisements du Terrain Tertiaire Miocène dans le Bassin Sous-Pyrénéen. Auch: J.A. Portes.

Lydekker, R. 1890. Catalogue of the fossil Amphibia and Reptilia in the British Museum (Natural History). IV. Anomodontia, Ecaudata, Caudata, and Labyrinthodontia. London: British Museum.

Mendelssohn, H., and H. Steinitz. 1943. A new frog from Palestine. Copeia 1943: 231-233.

Meyer, H. von. 1843. Summarische Uebersicht der fossilen Wirbelthiere des Mainzer Tertiär-Beckens, mit besonderer Rücksicht auf Weisenau. Neues Jahrbuch für Mineralogie, Geognosie, Geologie und Petrefakten-Kunde 1843: 379-410.

Meyer, H. von. 1845. Zur Fauna der Vorwelt. Fossile Saeugethiere, Voegel und Reptilien aus dem Molasse-Mergel von Oeningen. Schmerber: Frankfurt am Main.

Miklas, P.M. 2002. Die Amphibienfauna (Amphibia: Caudata, Anura) der obermiozänen Fundstelle Götzendorf an der Leitha (südliches Wiener Becken, Niederösterreich). Annalen des Naturhistorischen Museums in Wien 103: 161-211.

Młynarski, M. 1976. Discoglossus giganteus Wettstein-Westersheimb, 1955 (Discoglossidae, Anura) from the Miocene of Przeworno in Silesia (Poland). Acta Zoologica Cracoviensia 21: 1-12.

Prieto, J., M. Böhme, H. Maurer, K. Heissig, and H. Abdul Aziz. 2009. Biostratigraphy and sedimentology of the Fluviatile Untere Serie (Early and Middle Miocene) in the central part of the North Alpine Foreland Basin: implications for palaeoenvironment and climate. International Journal of Earth Sciences 98: 1767-1791.

Rage, J.-C., and S. Bailon. 2005. Amphibians and squamate reptiles from the late early Miocene (MN 4) of Béon 1 (Montréal-du-Gers, southwestern France). Geodiversitas 2: 413-441.

Rage, J.-C., and S. Hossini. 2000. Les Amphibiens du Miocène moyen de Sansan. Mémoires du Muséum National d'Histoire Naturelle 183: $177-217$.

Roček, Z. 1994. Taxonomy and distribution of Tertiary discoglossids (Anura) of the genus Latonia v. Meyer, 1843. Geobios 27: 717-751.

Roček, Z. 2005. Late Miocene Amphibia from Rudabánya. Palaeontographia Italica 90: 11-29.

Roček, Z. 2013. Mesozoic and Tertiary Anura of Laurasia. Palaeobiodiversity and Palaeoenvironments 93: 397-439.

Sanchiz, B. 1998a. Encyclopedia of Paleoherpetology, part 4, Salientia. München: F. Pfeil.

Sanchiz, B. 1998b. Vertebrates from the Early Miocene lignite deposits of the opencast mine Oberdorf (Western Styrian Basin, Austria). Annalen des Naturhistorischen Museums in Wien A99: 31-38.

Selmeier, A. 1990. Die Molasseflora von Öhningen. In Klassische Fundstellen der Paläontologie, vol. 2, ed. W.K. Weidert, 214-220. Korb: Goldschneck.

Špinar, Z. 1975. Miopelobates fejfari n. sp., a new representative of the family Pelobatidae (Anura) from the Miocene of Czechoslovakia. Věstník Ústředního Ústavu Geologického 50: 41-45. 
Špinar, Z. 1978. Latonia kolebabi Špinar. (In 1976 (Amphibia) and remarks on the "genus Miopelobates") In Paleontologická konference 1977, ed. V. Pokorný, 289-303. Prague: Charles University.

Stauber, H. 1939. Erforschungsgeschichte der Öhninger Fundstätten und ihrer Versteinerungen. Zentralblatt für Mineralogie, Geologie Paläontologie (B: Geologie und Paläontologie) 1939: 314-332.

Syromyatnikova, E., and Z. Roček. 2018. New Latonia (Amphibia: Alytidae) from the late Miocene of northern Caucasus (Russia). Palaeobiodiversity and Palaeoenvironments. https://doi. org/10.1007/s12549-018-0350-3.

Venczel, M. 2001. Anurans and squamates from the Lower Pliocene (MN14) Osztramos 1 locality (northern Hungary). Fragmenta Palaeontologica Hungarica 19: 79-90.

Venczel, M. 2004. Middle Miocene anurans from the Carpathian Basin. Palaeontographica (A: Paläozoologie und Stratigraphie) 271: 151-174.

Venczel, M., and J. Hír. 2013. Amphibians and Squamates from the Miocene of Felsőtárkány Basin, N-Hungary. Palaeontographica (A: Paläozoologie und Stratigraphie) 300: 117-158.
Venczel, M., and J. Hír. 2015. Lissamphibians and squamate reptiles from the early middle Miocene of Litke, Northern Hungary. Geobios 48: 491-504.

Venczel, M., and E. Ştiucă. 2008. Late middle Miocene amphibians and squamate reptiles from Tauţ, Romania. Geodiversitas 30: 731-763.

Villa, A., M. Delfino, À. Luján, S. Almécija, and D. Alba. 2017. First record of Latonia gigantea (Anura, Alytidae) from the Iberian Peninsula. Historical Biology. https://doi.org/10.1080/08912 963.2017.1371712.

Westphal, F. 1978. Tylototriton (Amphibia, Urodela) aus dem Obermiozän von Öhningen. Neues Jahrbuch für Geologie und Paläontologie, Monatshefte 1978(8): 491-501.

Wettstein-Westersheimb, O. 1955. Die Fauna der miozänen Spaltenfüllung von Neudorf a.d. March (ČSR). Amphibia (Anura) et Reptilia. Sitzungsberichte der Österreichischen Akademie der Wissenschaften, Mathematisch-Naturwissenschaftliche Klasse 164: 801-815. 